\title{
Review of Micro Strip Patch Antenna Characteristics Analysis and Bandwidth Enhancement by using U Slot Microstrip Patch Antenna
}

\author{
Vineeta Chouksey \\ NIIST Bhopal
}

\author{
Puran Gour \\ Associate Prof. \\ NIIST Bhopal
}

\begin{abstract}
Microstrip patch antennas (MPA) have been widely used for many years due to their inherent advantages In terms of their inherent advantages in terms of low cost, small size, easy integration, and low-profile characteristics. MPA is genrally used in modern communication devices. But inherently it has narrow bandwidth. So to enhance bandwidth various techniques are used. In this review paper the researchers will be enhance the bandwidth by be using dimensionally invariance resonance frequency (DIResF) method and using different techniques like using slots in the patch by changing height, dielectric constant and feed point.
\end{abstract}

\section{Keywords}

Bandwidth, coaxial feed, DIResF, FDTD, coplanar waveguide.

\section{INTRODUCTION}

The literature survey for a different works are proposed for microstrip patch antenna performance, fabrication and their application. Recently the demand for broad-bandwidth is increased rapidly.

For bandwidth enhancement [1], a discuss about DI and ResF technology separately for bandwidth enhancement. After analyze he combined both the techniques and then he concluded that the bandwidth enhancement that is approximately $31 \%$. In paper [2], a microstrip line fed U-slot patch is presents and achieved an impedance bandwidth $(\mathrm{VSWR}<2)$ of $18 \%$ and ranging from $5.65 \mathrm{Ghz}$ to $6.75 \mathrm{Ghz}$. By using this element, a $2 \times 2$ array is designed and manufactured. In paper[3], using printed circuit board (PCB) fabrication technique a rectangular U-slot patch antenna printed on conventional microwave substrate will be investigated experimentally. The analysis of antenna is based on 3-D FDTD method. Paper [4] presents a single-layer broad-band rectangular U-slot microstrip patch antenna provide $10 \%-40 \%$ impedance bandwidth even with nonair substrate. Paper[5] presents a broadband asymmetric U-slot patch antenna with narrow band. Due to reduction in probe diameter it causes in reduction in bandwidth . because of this $30 \%$ of bandwidth is achieved. In Paper [6], a U-shaped squar patch antenna is proposed which combined with the two parasitic tunning stubs which is fed by a coplanar waveguide (CPW). In [7], a MUSA is proposed i.e. modified U-slot patch antenna . on compairing with the standard U-slot geometry it provide a compact radiating structure with the reduced crosspolarization effect.

\section{REVIEW \& SURVEY}

\subsection{Characteristics Mode Analysis of a}

\section{class of Empirical Design Techniques for Prob-Fed, U-slot Microstrip Patch Antennas}

Mahrukh khan et al [1] developed a dimensionally invariance resonant frequency (DIResF) method which combines the features of DI method and ResF method. By using DIResF method, with the minimal and no probe location optimization, it shown to yield better bandwidth performance. DIResF method is the superior method to the other two methods that is Dimentional invariance(DI) and Resonant Frequency(ResF) method for rapid prototyping. Here analysis of characteristic mode is carried out for some critical parameters like substrate electrical thickness, slot width,feed location variations, probe radius to assess their dominant influence on the characteristics of the prob-fed symmetrically located, U-slot microstrip patch antenna on a single layer grounded substrate. The bandwidth obtain for DI and ResF techniques are $17.5 \%$ and $27.5 \%$ respectively but in the case of DIResF technique, it has the widest bandwidth that is $31 \%$. Due to edges of the finite size grounded dielectric substrate, the boresight gain patterns show the diffraction effects.

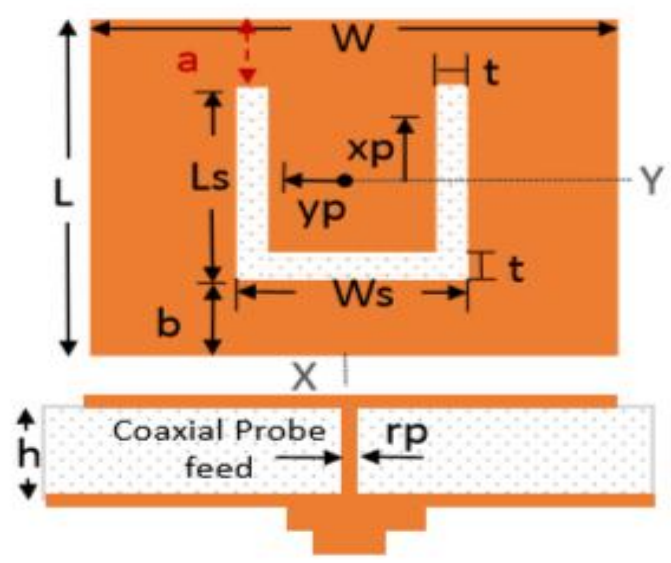

Fig.1. U-Slot loaded microstrip patch 

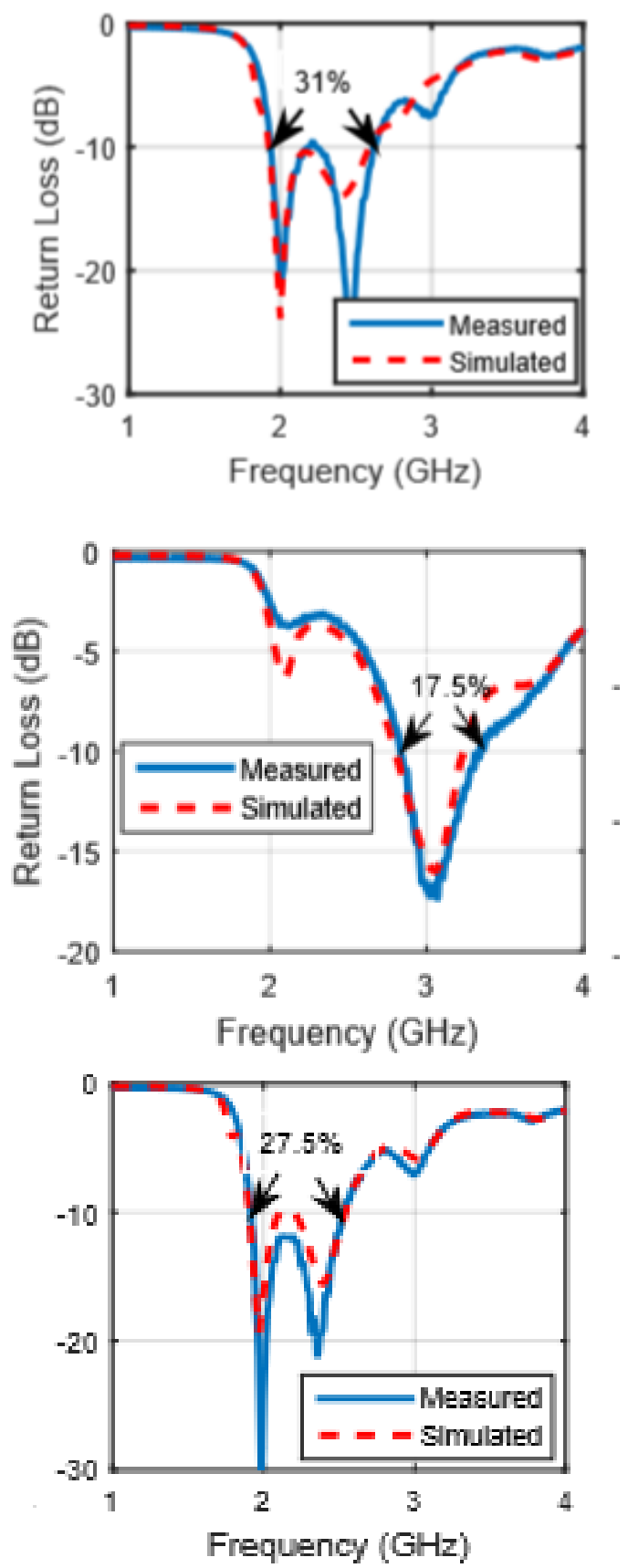

Fig. 2. Measured and simulated return loss on $(r=4.4, h=$ $11.811 \mathrm{~mm})$ for (a) DIResF (b) DI (mod) (c) ResF (mod)

\subsection{A Single Layer wideband U-slot Microstrip Patch Antenna Array}

H.Wang et al [2] design a $2 \times 2$ wideband microstrip antenna array using microstrip line fed U-slot patch. This array has a simple structure and has a wide bandwidth. The impedance bandwidth (VSWR<2) of $18 \%$ within the range of $5.65 \mathrm{GHz}$ to $6.78 \mathrm{GHz}$ has achieved. The peak gain of array is measured as $11.5 \mathrm{dBi}$. By using array module method, this array can be easily expanded into a larger array. In this paper, the radiation pattern, gain and crosss-polarization is also satisfactory within this bandwidth.

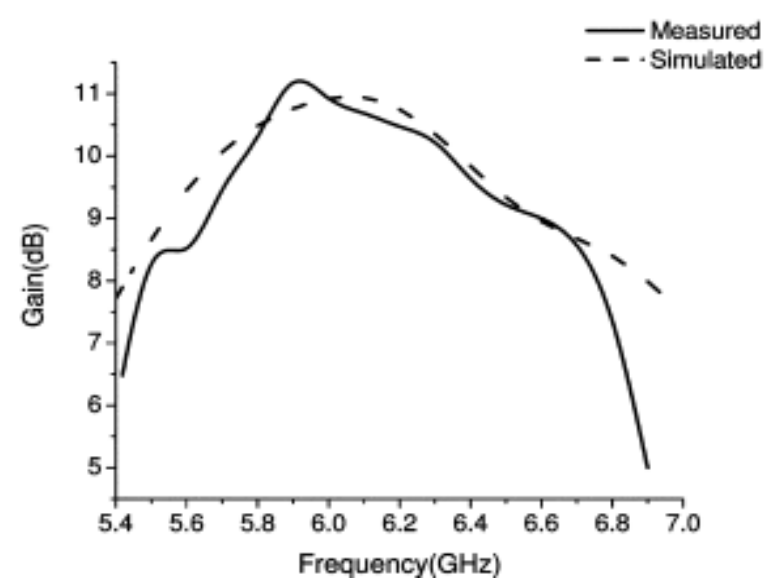

Fig.3. The simulated and measured gain of $2 \times 2$ array.

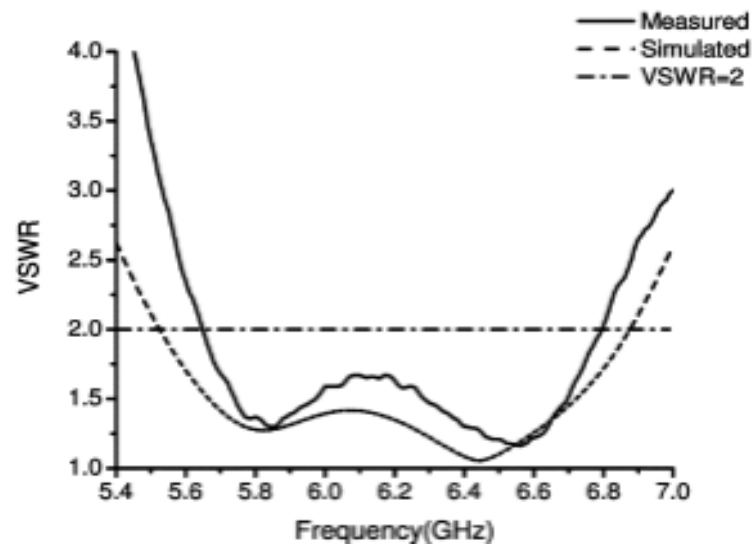

Fig.4. The simulated and measured VSWR.

\subsection{A Broad-Band U-slot Rectangular Patch Antenna on microwave substrate}

Kin-Fin Tong et al [3] presented a broad band U-slot rectangular patch antenna that is printed on a microwave substrate having dielectric constant 2.33. The presented antenna is fed by coaxial probe. The analysis of the antenna is based on the 3-D finite difference time domain (FDTD) method. The impedance bandwidth of the U-slot patch antenna on microwave substrate has achieved $27 \%$, centered around $3.1 \mathrm{GHz}$ with good pattern characteristics. The measured gain of the antenna is about $6.5 \%$.

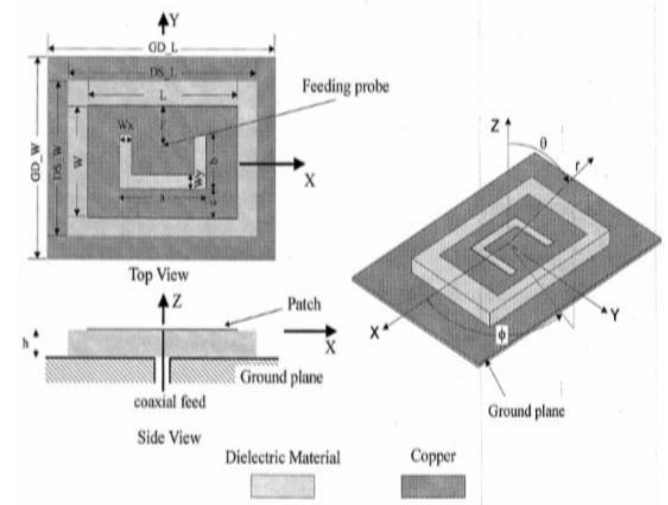

Fig 5. Geometry of a U-slot rectangular patch antenna printed on a microwave substrade. 


\subsection{Analysis and Design of Broad Band single-layer Rectangular U-slot microstrip Patch Antenna}

Steven Weigand et al [4] presents a new design procedure for the U-slot rectangular patch antenna. By combining structure's multiple resonant frequencies, a broad-band frequency response is produce and analyzed. A single layer Rectangular U-slot microstrip patch antenna with a wide operating bandwidth is present using coaxial feeding method. This antenna structure provide impedance bandwidth of $10 \%$ to $40 \%$.

Table 1 Dimensions and material properties of the initial $\mathrm{U}$-slot antenna used in the parametric studies

\begin{tabular}{c|c|c|c|c|c|c|c|c|c|c}
\hline $\begin{array}{c}A \\
{[\mathrm{~mm}]}\end{array}$ & $\begin{array}{c}B \\
{[\mathrm{~mm}]}\end{array}$ & $\begin{array}{c}C \\
{[\mathrm{~mm}]}\end{array}$ & $\begin{array}{c}D \\
{[\mathrm{~mm}]}\end{array}$ & $\begin{array}{c}E \\
{[\mathrm{~mm}]}\end{array}$ & $\begin{array}{c}F \\
{[\mathrm{~mm}]}\end{array}$ & $\begin{array}{c}H \\
{[\mathrm{~mm}]}\end{array}$ & $\begin{array}{c}R \\
{[\mathrm{~mm}]}\end{array}$ & $\begin{array}{c}T \\
{[\mathrm{~mm}]}\end{array}$ & $\begin{array}{c}\text { Offset } \\
{[\mathrm{mm}]}\end{array}$ & $\varepsilon_{G}$ \\
\hline 36.0 & 26.0 & 12.0 & 16.0 & 2.0 & 2.0 & 4.0 & 0.5 & 5.0 & 0.0 & 2.20 \\
\hline
\end{tabular}

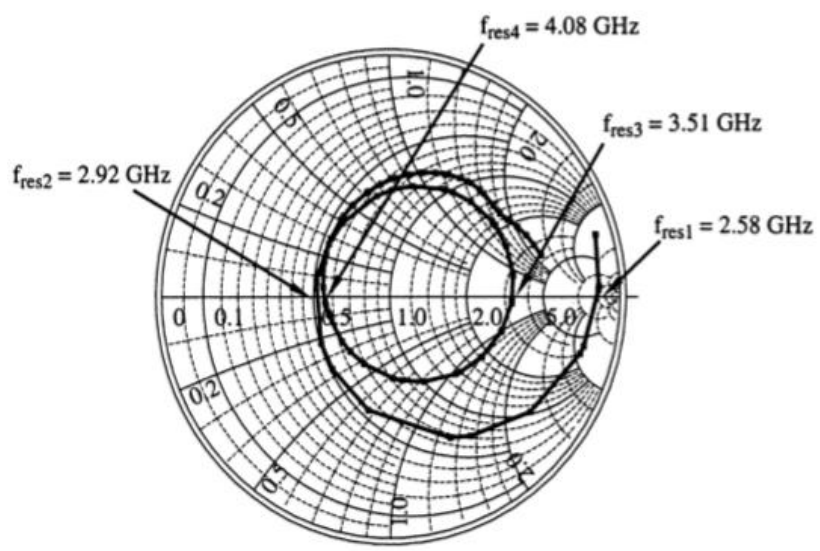

Fig.6 Stimulated input Impedance of the initial U-slot microstrip patch used in the parametric studies. The four resonant frequencies of the structure are indicated

\subsection{A practical miniaturized U-slot patch antenna with enhanced bandwidth}

G.F. khodoei et al [5] presents a broadband asymmetric U-slot patch antenna with the low probe diameter. Fr4 substrate with permitivity of 4.4 , having thickness $1.6 \mathrm{~mm}$ is used. The bandwidth is measured from 1.9 to $2.6 \mathrm{GHz}$ or $31 \%$ that is a result of 3 resonant frequencies in passband and that indicates a principle difference with symmetric U-slot patch antenna that has 2 resonant frequencies. In this antenna, a narrower probe is used than the corresponding probe and has higher inductance.

\subsection{U-shaped microstrip patch antenna with novel parasitic tuning stubs for ulta wideband applications}

M.Koohetani, M.Golpour et al [6] presents a novel compact microstrip antenna with the ultra wide bandwidth, which is fed by a coplanar waveguide(CPW). The antenna is a UShaped square patch antenna which combine with two parasitic tuning stubs. The size of the antenna is $24 \times 28 \times 0.787$ $\mathrm{mm}^{3}$. The antenna achieved an ultra wideband impedance bandwidth $\left(\mathrm{S}_{11}<-10 \mathrm{~dB}\right)$ as high as $129 \%$. The gain range measured from 1.6 to $5.3 \mathrm{dBi}$.

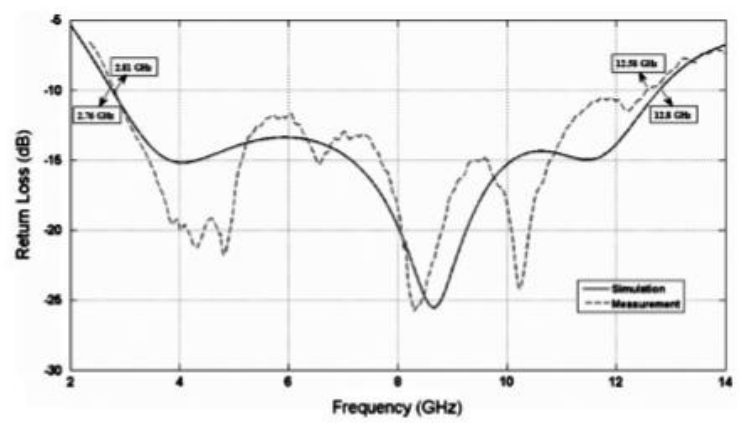

Fig.7. Measured and simulated return loss of fabricated antenna

\subsection{Modified U-slot patch antenna with reduced cross-polarization}

Sandra costanzo and Antonio costanzo et al [7] proposed a modified U-slot patch antenna (MUSA) to provide a compact radiating structure with the reduced cross-polarization effects. Here two different MUSA prototypes suitable for P-band and S-band applications are designed working at 1.8 and $7 \mathrm{GHz}$, by assuming a foam substrate $\left(€_{\mathrm{r}}=1.07\right)$. The first prototype that is P-band MUSA prototype work at a central frequency $\mathrm{f}_{\mathrm{o}}=450 \mathrm{MHz}$, with an operating bandwidth of about $15 \%$ that is useful for the P-sounding radar. A mean radiation efficiency approximately equal to $58 \%$ is derived here. The second Cband MUSA prototype is working at a central operating frequency $\mathrm{f}_{\mathrm{o}}=4.3 \mathrm{GHz}$ by using the same substrate with an operating bandwidth equal to $20 \%$. This configuration for the proposed antenna can be successfully adopted for satisfying broadband and high-speed data transfer requirements typical of modern communication systems like wireless local area networks.

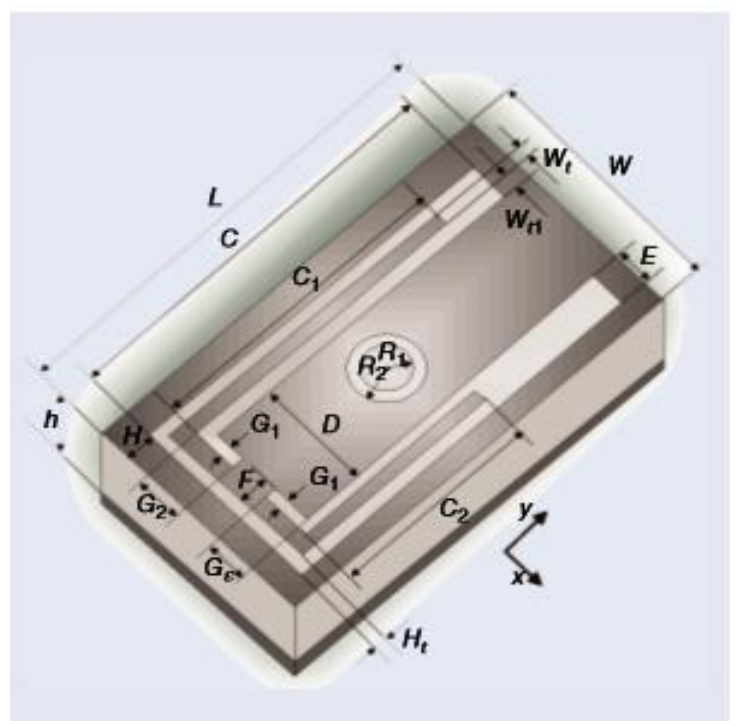

Fig. 8 The MUSA layout 


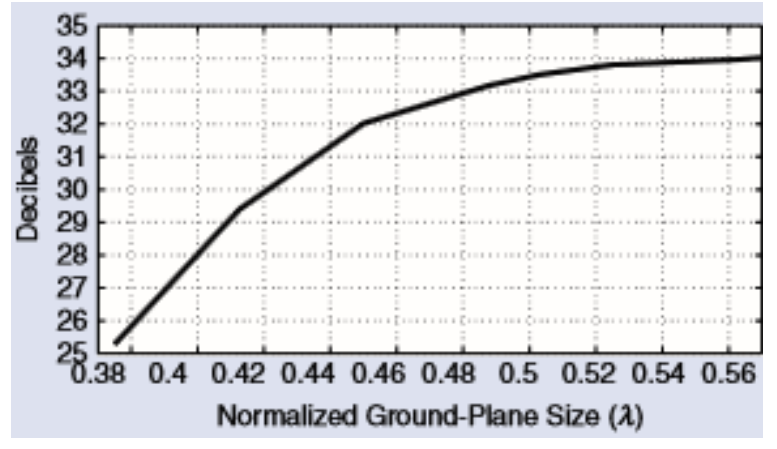

Fig. 9 The difference between the copolar and crosspolar levels versus the normalized groung-plan size

\subsection{Analysis of broad band U-slot} microstrip patch antenna

J.A. Ansari and Brij Ram et al [8] presents a broad band Uslot microstrip Patch antenna on a single layer foam substrate using equivalent circuit concept. To obtain the optimum values for broadband operation the effect of feed position and substrate height are also analyzed. In this paper two resonant frequencies are observed at 4.02 and $5.04 \mathrm{GHz}$ giving broadband operations. The bandwidth of the proposed antenna is found to be $33.52 \%$.

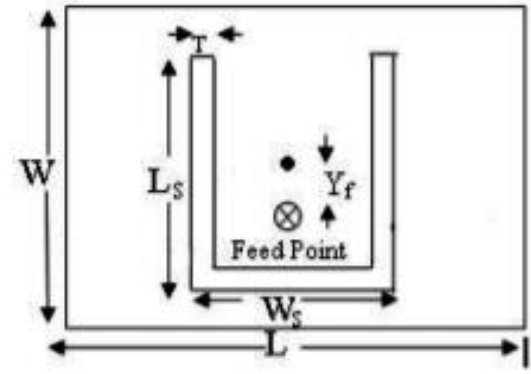

(a)

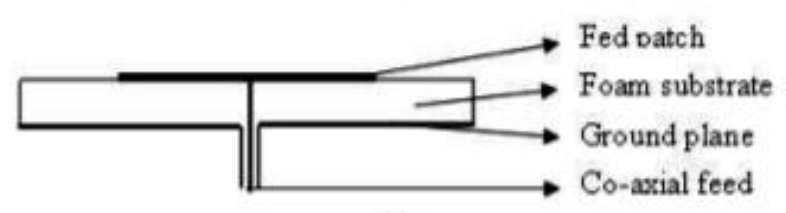

(b)

Fig 10 (a) Top view of the proposed antenna, (b) Slide view of the proposed antenna

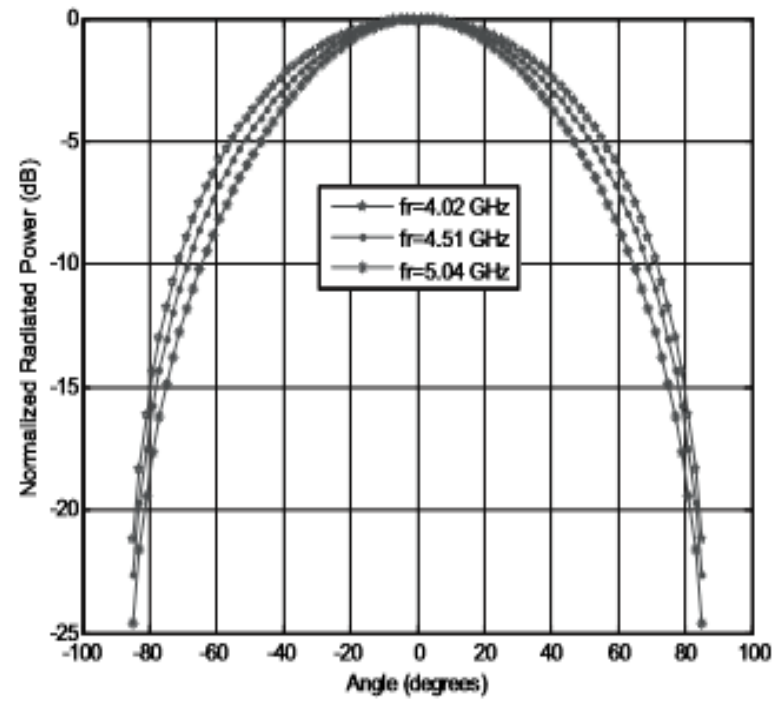

Fig 11. Variation of radiation paternal different frequencies

Table 2: Comparison of different parameter for micro strip patch antenna taken from refrence

\begin{tabular}{|c|c|c|c|c|}
\hline $\begin{array}{c}\text { NAME } \\
\text { OF } \\
\text { JOURN } \\
\text { AL }\end{array}$ & $\begin{array}{c}\text { IEEE } \\
\text { TRANSA } \\
\text { CTIONS } \\
\text { ON } \\
\text { ANTENN } \\
\text { AS AND } \\
\text { PROPAG } \\
\text { ATION }\end{array}$ & $\begin{array}{c}\text { IEEE } \\
\text { ANTE } \\
\text { NNAS } \\
\text { AND } \\
\text { WIRE } \\
\text { LESS } \\
\text { PROP } \\
\text { AGAT } \\
\text { ION } \\
\text { LETT } \\
\text { ERS }\end{array}$ & $\begin{array}{c}\text { IEEE } \\
\text { TRANSA } \\
\text { CTIONS } \\
\text { ON } \\
\text { ANTENN } \\
\text { AS AND } \\
\text { PROPAG } \\
\text { ATION }\end{array}$ & $\begin{array}{l}\text { Progress } \\
\text { In } \\
\text { Electroma } \\
\text { gnetics } \\
\text { Research } \\
\text { B }\end{array}$ \\
\hline $\begin{array}{c}\text { Publicat } \\
\text { ion }\end{array}$ & IEEE & IEEE & IEEE & \\
\hline Year & 2016 & 2008 & 2000 & 2008 \\
\hline Author & $\begin{array}{l}\text { Mahrukh } \\
\text { Khan, } \\
\text { Deb } \\
\text { Chatterjee }\end{array}$ & $\begin{array}{c}\text { H. } \\
\text { Wang, } \\
\text { X. B. } \\
\text { Huang } \\
\text {, and } \\
\text { D. G. } \\
\text { Fang }\end{array}$ & $\begin{array}{c}\text { Kin-Fai } \\
\text { Tong, } \\
\text { Kwai- } \\
\text { Man Luk,, } \\
\text { Kai-Fong } \\
\text { Lee, } \\
\text { Richard } \\
\text { Q. Lee }\end{array}$ & $\begin{array}{c}\text { G. F. } \\
\text { Khodaei, } \\
\text { J. } \\
\text { Nourinia, } \\
\text { and C. } \\
\text { Ghobadi }\end{array}$ \\
\hline
\end{tabular}




\begin{tabular}{|c|c|c|c|c|}
\hline Topic & $\begin{array}{c}\text { Characteri } \\
\text { stic Mode } \\
\text { Analysis } \\
\text { of a Class } \\
\text { of } \\
\text { Empirical } \\
\text { Design } \\
\text { Technique } \\
\text { s for } \\
\text { Probe- } \\
\text { Fed, } \\
\text { U-Slot } \\
\text { Microstrip } \\
\text { Patch } \\
\text { Antennas }\end{array}$ & $\begin{array}{c}\text { A } \\
\text { Single } \\
\text { Layer } \\
\text { Wideb } \\
\text { and U- } \\
\text { Slot } \\
\text { Micro } \\
\text { strip } \\
\text { Patch } \\
\text { Anten } \\
\text { na } \\
\text { Array }\end{array}$ & $\begin{array}{c}\text { A } \\
\text { Broa } \\
\text { d- } \\
\text { Band } \\
\text { U- } \\
\text { slot } \\
\text { Recta } \\
\text { ngula } \\
\text { r } \\
\text { Patch } \\
\text { Ante } \\
\text { nna } \\
\text { on } \\
\text { micr } \\
\text { owav } \\
\text { e } \\
\text { subst } \\
\text { rate. }\end{array}$ & $\begin{array}{c}\text { A } \\
\text { Practical } \\
\text { Miniaturiz } \\
\text { ed U-Slot } \\
\text { Patch } \\
\text { Antenna } \\
\text { With } \\
\text { Enhanced } \\
\text { Bandwidt } \\
\text { h }\end{array}$ \\
\hline $\begin{array}{c}\text { Dielectri } \\
\text { c } \\
\text { Sub. }\end{array}$ & $\begin{array}{c}\text { FR-4 } \\
\text { substrate }\end{array}$ & & & \\
\hline $\begin{array}{c}\text { Frequen } \\
\text { cy }\end{array}$ & $4 \mathrm{GHz}$ & $\begin{array}{c}6.2 \\
\mathrm{GHz}\end{array}$ & $3.1 \mathrm{GHz}$ & $2.05 \mathrm{GHz}$ \\
\hline $\begin{array}{c}\text { Bandwi } \\
\text { dth }\end{array}$ & $31 \%$ & $18 \%$ & $27 \%$ & $31 \%$ \\
\hline Gain & $5 \mathrm{dBi}$ & $\begin{array}{l}11.5 \\
\mathrm{dBi}\end{array}$ & $6.5 \mathrm{~dB}$ & \\
\hline $\begin{array}{c}\text { Return } \\
\text { loss }\end{array}$ & $-22 \mathrm{~dB}$ & & & $-34 \mathrm{~dB}$ \\
\hline
\end{tabular}

\section{CONCLUSION}

In this review, I have concluded that impedance bandwidth achieved nearly $30 \%$ which is very less. The achieved gain is also less so by using some technique like stub matching, impedance matching we will improve the bandwidth of proposed microstrip patch antenna.

\section{REFERENCES}

[1] Mahrukh khan, "Characteristics Mode Analysis of a class of Empirical Design Techniques for Prob-Fed, Uslot Microstrip Patch Antennas", IEEE transaction on antenna and propagation, volume issue 2016[doi 10.1109_TAP 2016.2556705].

[2] H. Wang, X. B. Huang, and D. G. Fang, " A Single Layer wideband U-slot Microstrip Patch Antenna Array", IEEE antenna and wireless propagation letters, vol.7, 2008.

[3] Kin-Fai Tong, Kwai-Man Luk, Senior Member, KaiFong Lee, and Richard Q. Lee, "A Broad-Band U-slot Rectangular Patch Antenna on microwave substrate",IEEE transactions on antennas and propagation, vol. 48, no. 6, june 2000.

[4] Steven Weigand, Greg H. Huff, Kankan H. Pan, and Jennifer T. Bernhard, "Analysis and Design of Broad Band single-layer Rectangular U-slot microstrip Patch Antenna", IEEE transactions on antennas and propagation, vol.51, no. 3, march 2003.

[5] G. F. Khodaei, J. Nourinia, and C. Ghobadi, "A practical miniaturized U-slot patch antenna with enhanced bandwidth", Progress In Electromagnetics Research B, Vol. 3, 47-62, 2008.

[6] M.Koohestani, M. Golpour, "U-shaped microstrip patch antenna with novel parasitic tuning stubs for ulta wideband applications", IET Microw. Antennas Propag., vol. 4, no. 7, pp. 938-946, 2010.

[7] Sandra Costanzo and Antonio Costanzo, "Modified Uslot patch antenna with reduced cross-polarization", IEEE Antennas Propag. Mag., vol. 57, no. 3, pp. 71-80, June 2015.

[8] J. A. Ansari and B. R. Ram, "Analysis of Broad-Band USlot Microstrip Patch Antenna,"Microwave and Optical Technology Letters, vol. 50, no. 4, pp. 1069-1073, April 2008. 